\title{
BENTUK HUNIAN SUKU BAJO AKIBAT PENGARUH INTERAKSI HUNIAN SUKU GORONTALO DI DESA TORISIAJE KABUPATEN POHUWATO PROVINSI GORONTALO
}

\author{
Amru Siola \\ Dosen Program Studi Teknik Arsitektur, Universitas Ichsan Gorontalo \\ Email : ichaq.arsitek@gmail.com
}

\begin{abstract}
Abstrak
Masyarakat pesisir, baik langsung maupun tidak langsung, menggantungkan kelangsungan hidupnya dari mengelola potensi sumberdaya kelautan. Seperti juga masyarakat yang lain, masyarakat nelayan menghadapi banyak masalah seperti politik, sosial dan ekonomi yang kompleks. Ragam masalah tersebut antara lain: 1) kemiskinan, kesenjangan sosial dan tekanan-tekanan ekonomi yang datang setiap saat, 2) keterbatasan akses modal, teknologi dan pasar sehingga mempengaruhi dinamika usaha, 3) kelemahan fungsi kelembagaan sosial ekonomi yang ada, 4) kualitas sumber daya manusia (SDM) yang rendah sebagai akibat keterbatasan akses pendidikan, kesehatan dan pelayanan publik, 5) degradasi sumberdaya lingkungan, baik di kawasan pesisir, laut maupun di pulau-pulau kecil, 6) belum kuatnya kebijakan yang berorientasi pada kemaritiman sebagai pilar utama pembangunan nasional. Permasalahan yang akan dikaji oleh peneliti dalam penelitian ini yaitu bagaimana wujud interaksi suku Gorontalo dengan suku Bajo di desa Torosiaje dan Bagaimana perubahan bentuk hunian suku Bajo di desa Torosiaje Kabupaten Pohuwato provinsi Gorontalo.

Metode yang digunakan dalam penelitian ini adalah metodologi kualitatif dan kuantitatif secara bersama-sama. Tampak rumah suku Bajo: dilihat dari tampak depan, belakang maupun samping rumah tradisional sudah mengalami perubahan bentuk. Hal yang paling spesifik bisa kita lihat pada tampak depannya dengan penambahan atap pelana yang merupakan ciri khas rumah suku Gorontalo. Kecenderungan perubahan bentuk hunian suku Bajo mengikuti bentuk rumah tradisional suku Gorontalo sangat kuat dipengaruhi oleh adanya pengaruh interaksi dengan suku Gorontalo di desa Torosiaje.
\end{abstract}

Kata kunci: Bentuk Hunian, Perubahan Bentuk, Interaksi, Suku Bajo, Torosiaje

\begin{abstract}
The coastal communities, either directly or indirectly, pinning its survival of managing maritime. resource potential At the same time as other public, the community there are approximately fishermen who face many problems as in politics, social and economic infrastructure through which often bump into. Variety of the problem among other: 1) poverty, the gap in social and economic pressures that come in every when; 2) to limited access capital, technology and the market so as to affect The dynamics of business; 3 ) weakness function existing economic, social institutions; 4 ) the quality of human resources (SDM ) as human resources that are low due to limited access to education, health and public service; 5) degradation environment resources, in coastal areas, sea and small islands, 5) have strong policies that concern itself with kemaritiman as the main pillar of national development. Problems examined by researchers in this research which are how form interaction the Gorontalo to the bajo in the village torisiaje and how the the form of occupancy the bajo in the village Torisiaje regency Pohuwato of Gorontalo province.

Methods used in this research is in bersama-sama qualitative and quantitative methodology. The house looked Bajo: Seen from the foreground, the back and across from the traditionally have had a change of form. The most specific we can look at look front of him with the addition of a gable which is typical of the tribe of Gorontalo. The issue that was most specific can we were seeing on there seems to be a front of him by the addition of of a gable that are characteristic the house of the tribe of seven provinces starting with Gorontalo. The tendency of changes of form occupancy of the tribe of bajo followed the form of the tribe traditional gorontalo very strongly influenced by the influence of interaction with tribes in the Gorontalo village Torosiaje.
\end{abstract}

Keywords: The form of occupancy, change of form, interaction, the tribe of bajo, torosiaje

\section{PENDAHULUAN}

Terbentuknya permukiman komunitas suku Gorontalo dan suku Bajo di desa Torisiaje dilatarbelakangi oleh sebagian besar masyarakatnya yang mempunyai sumber mata pencaharian sebagai nelayan. Mereka membentuk permukiman kampung nelayan untuk memudahkan aksesibilitas terhadap kegiatan sehari-hari, sebagai nelayan, mulai dari penangkapan ikan ataupun hasil-hasil laut lainnya sampai pada pemasaran. Semuanya dilakukan di kampung ini.Bentuk-bentuk unik yang ditampilkan merupakan cerminan identitas lokal yang memperkaya khasanah budaya nusantara. 
Permukiman Suku Bajo di Torosiaje memiliki keunikan tersendiri yaitu permukiman tersebut dibangun di atas laut yang benar-benar terpisah dari daratan, Kedekatan ini terbukti ketika pemerintah pada 1982 berupaya untuk merelokasi para penduduk Suku Bajo untuk dirumahkan dengan diberikan sepetak lahan untuk bercocok tanam, namun mereka tak betah dan satu demi satu anggota suku ini meninggalkan lokasi relokasi dan kembali ke laut. Barangkali ungkapan jika Suku Bajo itu lahir, hidup, dan mati di laut adalah benar adanya. Rumah-rumah penduduk Torosiaje berbentuk rumah panggung dengan tinggi sekitar 3-4 meter dari atas permukaan air laut. Di depan rumahrumah panggung ini di bawahnya terdapat (Karamba) kandang ikan terapung sebagai penunjang ekonomi Suku Bajo di Torosiaje ini. Permukiman Suku Bajo di Torosiaje memiliki keunikan tersendiri yaitu permukiman tersebut dibangun di atas laut yang benar-benar terpisah dari daratan, Lihat Gambar 1

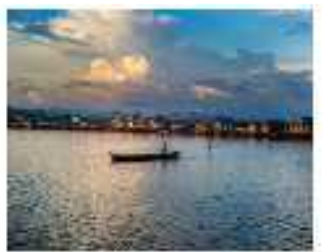

Prualiama Suku Baje Twvoigjc L.tut

Gambar 1. Permukiman Suku Bajo di Torosiaje. Sumber: Dokumen Pribadi, 2017

Kedekatan ini terbukti ketika pemerintah pada 1982 berupaya untuk merelokasi para penduduk Suku Bajo untuk dirumahkan dengan diberikan sepetak lahan untuk bercocok tanam, namun mereka tak betah dan satu demi satu anggota suku ini meninggalkan lokasi relokasi dan kembali ke laut. Barangkali ungkapan jika Suku Bajo itu lahir, hidup, dan mati di laut adalah benar adanya. Rumahrumah penduduk Torosiaje.

Hunian suku Bajo pada awalnya di atas bidok (perahu) sampai tahun 1930-an. Kemudian pada awal tahun 1935 mereka mulai membangun kampoh (tempat tinggal tetap). Babaroh ini merupakan tempat tinggal sementara suku Bajo untuk istirahat dan mengolah hasil laut. Semua material konstruksinya berasal dari lingkungan sekitarnya seperti kayu bakau sebagai tiang penyangga, rumbia untuk penutup atap dan bambu sebagai lantai atau dinding. Setelah merasa cocok tinggal di Torisiaje, akhirnya mereka mengembangkan hunian mereka dari babaroh menjadi papondok Soesangobeng (1977).

Dimensi papondok sudah lebih besar dari babaroh namun material konstruksinya masih sama yakni bahan bangunan berasal dari lingkungan sekitar tempat tinggal mereka. Pada tahun 1956 bentuk papondok ini dikembangkan lagi menjadi rumak seperti bentuk hunian mereka saat ini.

Berdasarkan uraian latar belakang tersebut, maka permasalahan yang akan dikaji oleh peneliti dalam penelitian ini adalah Bagaimana wujud interaksi suku Gorontalo dengan suku Bajo di desa Torisiaje yang mengakibatkan adanya perubahan bentuk hunian suku Bajo yang ada di desa Torisiaje Kabupaten Pohuwato provinsi Gorontalo.

a. Budaya

Koentjaraningrat (2009) memilah kerangka kebudayaan dalam konteks penciptaan tatanan ruang hunian dan membaginya dalam tiga wujud. Yaitu budaya sebagai sistem adat istiadat, gagasan kompleks dari ide-ide, nilai-nilai, norma-norma, dan peraturan. Budaya sebagai sistem sosial, suatu aktivitas atau tindakan yang berpola dari manusia dalam masyarakat. Dan budaya sebagai sistem kebudayaan fisik sebagai benda-benda hasil kebudayaan manusia yang merupakan seluruh total hasilfisik dari aktivitas serta karya manusia dalam masyarakat.

Rumah tradisional merupakan manifestasi dari nilai sosial budayamasyarakat yang erat kaitannya dengan nilai sosial budaya penghuninya, yang dalamproses penyusunannya menggunakan dasar norma-norma tradisi (Rapoport, 1969).

\section{b. Kajian Pustaka}

\section{Rumah}

Menurut Undang-Undang Nomor 4 Tahun 1992 Tentang Perumahan dan Permukiman dikatakan bahwa yang dimaksud dengan rumah adalah bangunan yang berfungsi sebagai tempat tinggal atau hunian dan sarana pembinaan keluarga.

\section{Rumah dan Budaya}

Hubungan antara rumah dan kebudayaan menurut Rapoport (1969) bahwa rumah dan lingkungan merupakan suatu ekspresi masyarakat tentang budaya, termasuk didalamnya agama, keluarga, struktur sosial dan hubungan sosial antar individu. Selanjutnya Rapoport mengatakan bahwa dalambanyak kasus faktor budaya menjadi sangatpenting sebagai faktor yang menentukan bentuk rumah. Adapun ikim merupakan faktor yang memodifikasi bentuk.

\section{Ruang dan Privasi}

Ruang privat tempat pembinaan etika moral penghuninya. Privat atau privasi menunjukkan adanya batas-batas perilaku dalam interaksi sosial dimana privasi adalah kontrol selektif interaksi antara manusia secara individu atau kelompok dengan yang lainnya. Batasan privasi berupa normanorma yang disepakati oleh kelompok yang kemudian diwujudkan dalam batas-batas fisik spasial.

\section{Tradisi dan Tradisional}

Tradisi adalah sebuah praktek, kebiasaan, atau cerita yang dihafalkan dan diwariskan dari generasi ke generasi, awalnya tanpa memerlukan sebuah sistem tulisan. Tradisi sering dianggap menjadi 
kuno; dianggap sangat penting untuk dijaga. Namun demikian ada juga beberapa tradisi yang memang sengaja diciptakan demi mencapai tujuantujuan tertentu; sebagai alat untuk memperkuat kepentingan atas kalangan tertentu dan lain sebagainya. Tradisi semacam itu ternyata dapat diubah sesuai dengan kebutuhan saat itu dan perubahan itu masih bisa diterima sebagai bagian dari tradisi kuno.

Tataran teoritis, tradisi dapat dipandang sebagai informasi atau terdiri atas informasi. Informasi yang dibawa dari masa lalu ke masa kini dan dalam konteks sosial tertentu. Sehingga informasi ini bisa dianggap sebagai bagian yang paling mendasar meski secara fisik ada tindakan-tindakan atau aktifitas tertentu yang secara terus menerus juga dilakukan pengulangan-pengulangan sepanjang waktu. Kebudayaan atau sebuah hasil karya yang dianggap berhasil dan memiliki legitimasi dalam kurun waktu yang cukup panjang dan bahkan sangat panjang (lama) yang diikuti oleh generasi generasi berikutnya secara turun temurun.

\section{Arsitektur Tradisional}

Arsitektur tradisional berkembang mencapai bentuknya yang sekarang melalui proses dalam kurun waktu lama dan sukar diketahui secara pasti sejarah dan konsep-konsep bentuk bangunannya karena diturunkan dari generasi ke generasi tanpa peninggalan baik berupa gambar maupun tulisan. Demikian juga konsep-konsep pola pikir yang abstrak, kepercayaan, budaya, adat istiadat, iklim, lingkungan dan lain-lain bentuk arsitektural tidak dapat diketahui secara pasti. Dan juga arsitektur tradisional terbentuk oleh adanya ikatan geografis dari sekelompok manusia atau masyarakat, sehingga terjadi interaksi antara manusia dengan manusia dan antara manusia dengan alam, dari waktu ke-waktu dari generasi ke-generasi. Indonesia yang terdiri dari berbagai suku masingmasing mempunyai budaya adat kebiasaan bahkan bahasa, kepercayaan, terungkap secara fisik antara lain dalam bentuk seni, artefak dan arsitektur yang khas.

\section{Rumah Tinggal Tradisional}

Arsitektur rumah tinggal tradisional di Indonesia tentunya berbeda dengan arsitektur rumah tinggal di "Barat". Bentuk yang hadir pada arsitektur rumah tinggal tradisional di Indonesia selalu dipertalikan dengan makna "yang lebih dalam", yang berada dibalik bentukan yang terjadi, tidak berhenti hanya pada yang tersurat atau kasat mata. Penggunaan ruang yang terjadi tidak hanya untuk menampung aktivitas fisik sehari-hari, tetapi juga spritual untuk memperoleh ketenangan batin/jiwa. Apalagi kalau kita memahami makna tersebut dengan pendekatan "Emik"yaitu melihat suatu gejala dari sudut pandang para pelaku sosialnya, bukan dari para penelitinya. Akan banyak aspek yang dapat diungkap dibalik bentukan arsitektur yang terjadi.
Pola hunian suku Bajo yang hanya mempunyai dindingnya terbuat kombinasi kayu dan anyaman bambu. Sedangkan bagian atap dari daun rumbia, terbuat \ kombinasi kayu dan anyaman bambu. Sedangkan bagian atap dari daun rumbia.

\section{Gaya Arsitektur Bangunan Suku Bajo Di} Desa Torosiaje

Analisis Perkembangan Struktur Rumah Dari hasil pengamatan lapangan rumah suku bajo dapat di kelompokkan dalam tiga tipe yaitu tipe 1 adalah rumah panggung yang berbahan lokal, tipe 2 adalah rumah panggung dengan tiang beton cetak, tipe 3 rumah tidak panggung dan berdinding beton.

- Rumah Suku Bajo Type 1

Type 1 ini adalah bangunan rumah tinggal suku bajo yang berbentuk rumah panggung. Bangunan ini didirikan dengan struktur utama yaitu berupa kayu berjenis Posi-posi yang merupakan kayu lokal daerah tersebut dengan sistem sambungan berupa takikan kayu yang dipaku pada bagian bawah rumah dan ikatan tali enau pada bagian struktur atap.
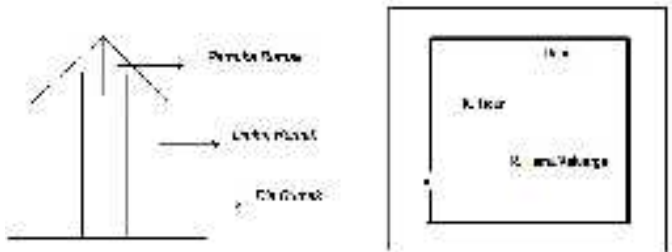

Gambar 2. Susunan Vertikal dan Horisontal Rumah Tradisional Suku Bajo Sumber: Jumran, (2010)

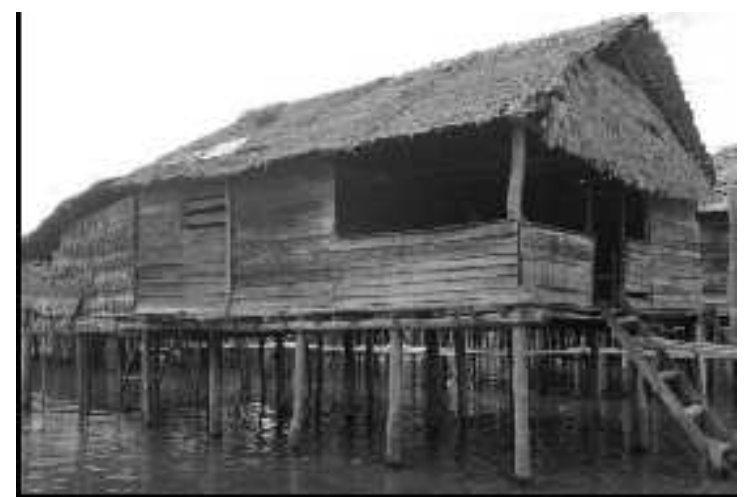

Gambar 3, Rumah Panggung Suku Bajo

Bagian dari struktur bangunan ini adalah sebagai berikut :

- Tiang

Tiang yang merupakan struktur utama bangunan, ditancapkan langsung ke dalam pasir sedalam \pm 50 centimeter. Pola tiang rumah berbentuk grid kubus dengan jarak bentang $5 \times 6$ meter. Bangunan ini memiliki dua macam tiang yaitu tiang yang menjadi penyangga kuda-kuda atap (biasa berukuran panjang $\pm 4 \mathrm{~m}$ ) dan tiang yang menjadi menjadi penyangga tiang lantai (biasa berukuran panjang $\pm 1,5 \mathrm{~m}$ ).

Semua tiang yang digunakan berbahan kayu ( kayu posi-posi sejenis kayu bakau yang tahan terhadap air laut). Kayu Posi-posi merupakan kayu 
lokal yang banyak terdapat di daerah tersebut, diameter kayu yang digunakan untuk tiang adalah sekitar $15-20 \mathrm{~cm}$. Kayu batangan tersebut langsung digunakan utuh karena jenis kayu tersebut tumbuh lurus tegak sehingga sangat ideal digunakan sebagai tiang bangunan.

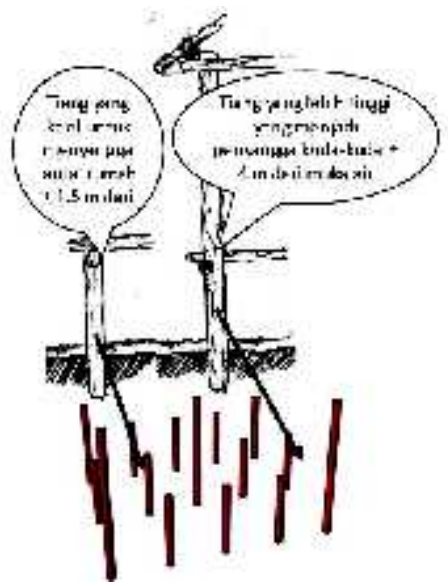

Gambar 4. Konstruksi Tiang Rumah Suku Bajo

\section{- Lantai}

Tidak ada pola khusus pada pengaturan lantai, struktur lantai tersusun atas batangan kayu utuh sebagai penopang lantai (berfungsi sebagai penyangga/balok lantai) dan papan kayu digunakan sebagai penutup bahan lantai, seperti pada gambar 3.5. Balok lantai pertama ditakik dan di pakukan ke tiang. Balok lantai kedua disusun dengan rapat berjarak $\pm 40 \mathrm{~cm}$ dan dipakukan ke tiang pertama. Lalu ditutup dengan papan yang di pakukan ke balok kedua. Sebelum papan digunakan sebagai penutup lantai, masyarakat suku Bajo menggunakan kayu nibong yang dicacah hingga menjadi datar. Pohon Nibong sejenis pohon pinang yang banyak tumbuh daerah tersebut, kemudian masyarakat suku Bajo beralih ke papan yang berasal dari kayu posi-posi.

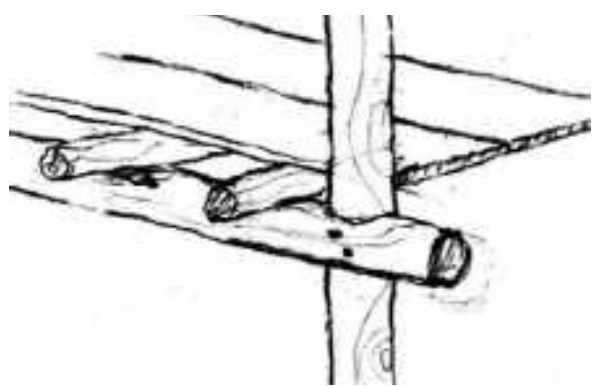

Gambar 4. Konstruksi Lantai Rumah Suku Bajo

- Dinding

Bentuk struktur dinding menggunakan batang pohon nibong yang digunakan sebagai bahan dinding dengan bentuk sambungan ikat. Bahan dinding tersebut telah mengalami perubahan, sebagai pengganti adalah bahan dari kayu (papan) dengan bentuk sambungan yang menggunakan paku.

d) Atap
Bentuk atap yang digunakan masih berbentuk asli yaitu atap pelana dengan system struktur menggunakan sistem sambungan ikat. Penutup atap menggunakan bahan rumbia yang dikenal juga sebagai atap nipa

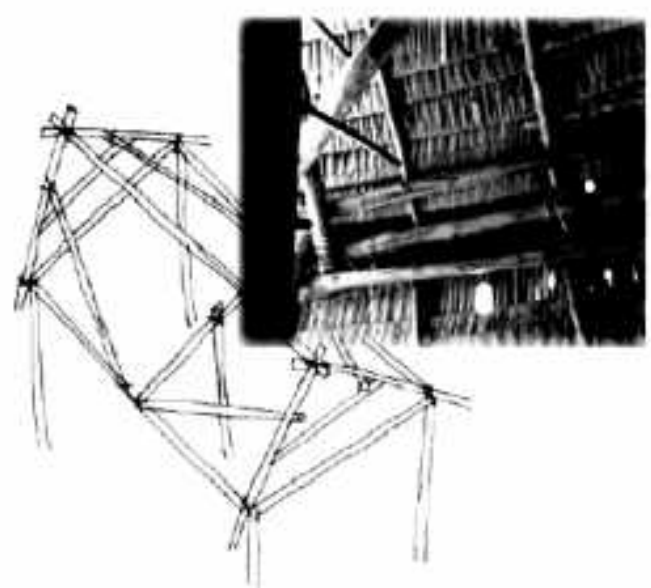

Gambar 5. Konstruksi Atap Rumah Suku Bajo

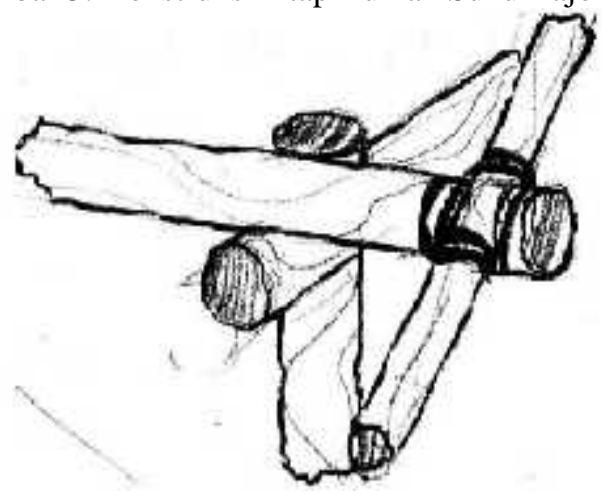

Gambar 6. Sistem Struktur Ikat Atap Rumah Suku Bajo

1. Rumah Suku Bajo Type 2

Bangunan ini didirikan dari perpaduan konstruksi beton dan kayu, dimana tiang utama dari bahan beton dan upper struktur dari bahan kayu, yang merupakan hasil program pembangunan dari pemerintah untuk pemenuhan hunian bagi warga suku Bajo.

a. Tiang/Pondasi

Tiang/Pondasi merupakan struktur utama bangunan, dididrikan langsung ke dalam pasir sedalam \pm 1 meter. Pola tiang rumah berbentuk grid kubus dengan ukuran dari as-as 5 x 6 meter.

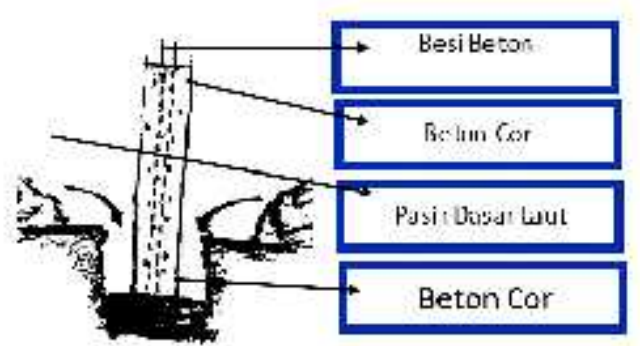

Gambar 7. Tiang Rumah Suku Bajo Type 2 b. Lantai 
Pola Lantai diatur dengan lebih baik, struktur lantai disusun dengan balok Lantai kayu dan papan sebagai penututp Lantainya. Balok lantai pertama ditakik dan dipakukan ke tiang. Balok lantai kedua disusun dengan rapat berjarak $\pm 40 \mathrm{~cm}$ dan dipakukan ke tiang pertama, kemudian ditutup dengan papan yang di pakukan ke balok kedua, papan sebagai penutup lantai.

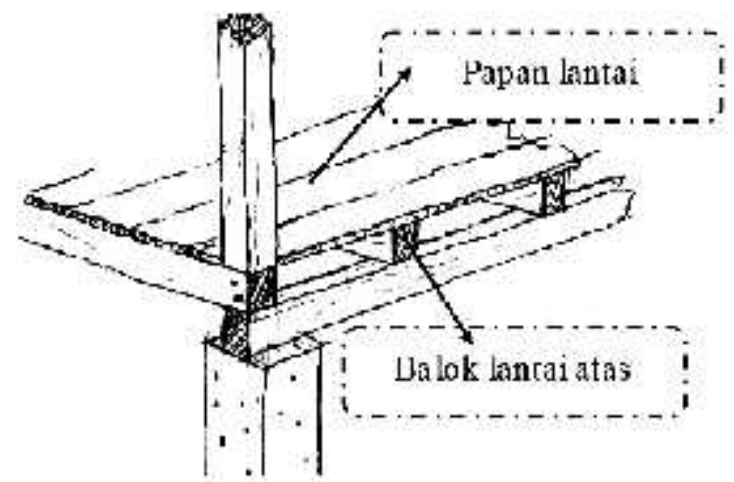

Gambar 8. Lantai Rumah Suku Bajo Type 2

c. Dinding

Struktur dinding menggunakan bahan dari kayu (papan) dengan bentuk sambungan yang menggunakan paku.

d. Atap

Berbentuk atap pelana dengan sistim struktur menggunakan kuda-kuda dan bahan atap seng gelombang sebagai penutup atap. Terdapat Tiang raja sebagai struktur utama, dan balok kaki kudakuda serta balok gording sebagai penyangga Penutup berupa seng

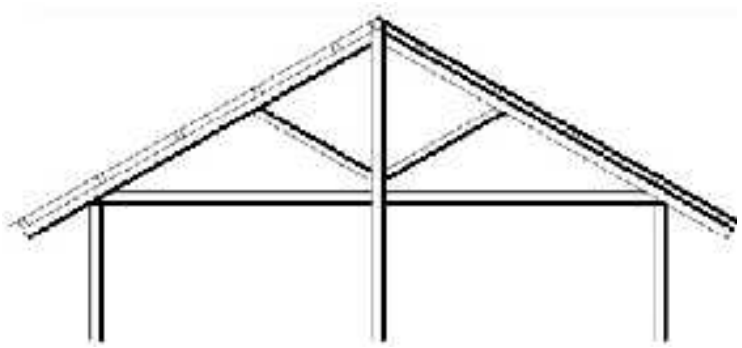

Gambar 9. Atap Rumah Suku Bajo Type 2

\section{Arsitektur Rumah Tinggal Tradisional Gorontalo}

a. Karakteristik Rumah Tinggal Tradisional Masyarakat Gorontalo

Karakteristik rumah tinggal masyarakat gorontalo pada zaman dahulu dapat dikelompokkan menjadi 3 kategori, yaitu:

1) Rumah tinggal yang dihuni oleh Raja/golongan bangsawan.

2) Rumah tinggal yang dihuni oleh orang berada/kaya

3) Rumah tinggal yang dihuni oleh rakyat kebanyakan/rakyat biasa (golongan menengah ke bawah).
Ketiga kategori dapat dijelaskan sebagai berikut: Pola dan bentuk bangunan segiempat utuh dan berbentuk rumah panggung. Jenis tiang dibagi 3 jenis yaitu 2 buah tiang utama (wolihi) yang menerus dari tanah ke atap, 6 buah tiang di serambi depan dan tiang dasar (potu) bervariasi tergantung kategori rumah, yakni Formasi dan jumlah tiang, $4 \mathrm{x}$ 8 atau 32 tiang untuk golongan bangsawan atas termasuk raja, 4 × 6, 4 × 7 atau 24 dan 28 tiang untuk golongan bangsawan menengah atau golongan berada/kaya, 4 x 5 atau 20 tiang untuk rumah rakyat kebanyakan/biasa Untuk kategori pertama bukti otentik tidak ditemukan lagi di lapangan, analisis dilakukan dengan melihat ciri umum yang terdapat pada golongan bangsawan menengah dengan memadukan hasil wawancara dengan pemuka adat/budayawan.

Fungsi dan formasi spasial tata ruang rumah secara vertikal terbagi tiga, masing-masing; tahuwa (ruang bawah/kolong) merupakan ruang bagian bawah tempat pajangan benda-benda budaya, biasanya dipasang alat tenun untuk menenun sarung dari benang kapas, menyimpan hasil bumi serta menyimpan peralatan pertanian, ruang tengah/badan rumah dan ruang atas/atap

Secara horisontal ruang terbagi 3 bagian, yakni: surambe atau ruang depan/teras (tempat menerima tamu laki-laki), ruang tengah/bangunan induk terdiri dari duledehu/hihibata (tempat menerima tamu perempuan), huali (kamar/tempat istirahat), dulawonga (ruangan pada bagian belakang yang dipakai untuk melepaskan lelah, hantaleya (teras samping kiri dan kanan rumah agak rendah dari bagian induk hanya terdapat pada rumah raja yang berfungsi sebagai selasar dan pengawal raja.

Khusus untuk rumah raja pada jaman dahulu berorientasi ke alun-alun (lapangan). Perletakan Tu'adu (tangga) pada mulanya hanya satu yang diletakkan di tengah tegak lurus bersandar pada duledehu/serambi dengan jumlah anak tangga 5 atau 7. Kemudian berkembang menjadi 2 tangga yang terletak disamping kiri dan kanan. Perkembangan terakhir merupakan pengaruh zaman Belanda. Jumlah anak tangga 7 untuk rumah bangsawan dan 5 untuk rakyat biasa. Dimensi bangunan bervariasi tergantung dari jumlah petak/besar ruang sesuai dengan status sosial penghuni.

Bentuk atap bersusun 2 dengan lisplank yang dihiasi ornamen untuk rumah bangsawan, sedang untuk golongan berada/menengah atap bersusun sebagian dihiasi dengan ornamen dan untuk golongan rakyat biasa atapnya sebagian bersusun dan sebagian tidak bersusun. Perkembangan terakhir perbedaan status sosial tidak lagi dapat dibedakan berdasarkan susunan atapnya.

Penggunaan jalamba (ornamen yang terletak pada bagian atas pintu/jendela dan ornamen yang menghias reiling tangga dan teras) pada golongan bangsawan berbentuk silang dengan berbagai variasi sementara untuk golongan rakyat biasa berbentuk 
silang tetapi dengan model yang lebih sederhana. Berbagai bentuk geometris lain berkembang setelah masuknya islam dengan berbagai variasi.

b. Tinjauan Filosofis Rumah Tinggal Tradisional Masyarakat Gorontalo

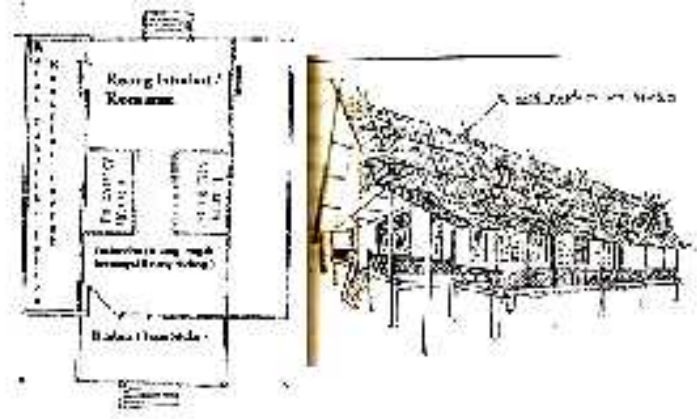

Gambar 10: Bele Li Tidulu Sumber: Sanggar Mbui Mbungale

Filosofi adalah latar belakang alam pikiran yang melandasi penentuan bentuk, tata ruang, bahan, serta upacara yang dipakai dalam perwujudan arsitektur. Beberapa filosofi rumah tradisional Gorontalo:

\section{1) Bentuk}

Sebagaimana bentuk rumah tradisional lainnya, rumah masyarakat gorontalo berbentuk panggung yang merupakan analogi dari bentuk tubuh manusia yang terdiri dari kaki, badan dan kepala berupa kolong/tiang badan rumah dan atap. Terdapat keseragaman pada proporsi rumah hal ini disebabkan filosofi yang tekait dengan ukuran rumah baik secara vertikal maupun secara horisantal. Untuk mengukur ketinggian, panjang dan lebar rumah dengan menggunakan depa, dengan aturan 1 depa dikurangi 1 jengkal hasil pengurangan dibagi 8 . Angka 8 memberi makna keadaan yang selalu terjadi pada diri manusia, yakni : rahmat, celaka, beruntung, kerugian, beranak, kematian, umur dan hangus. Jika angka tersebut berakhir pada yang tidak baik maka harus ditambah atau dikurangi satu. Jenis tiang dibedakan atas:

Tiang utama (wolihi) Sebanyak 2 buah ditancap di atas tanah langsung ke rangka atap. Tiang ini sebagai perlambang janji atau ikrar persatuan dan kesatuan yang kekal abadi antara dua bersaudara Gorontalo-Limboto (janji lou dulowo mohutatoHulontalo-Limutu) pada tahun 1664. Selain itu angka 2 melambangkan delito (pola) adat dan syariat sebagai falsafah hidup masyarakat yang harus dipegang teguh baik dalam pemerintahan maupun dalam kehidupan sehari-hari.

Tiang depan sebanyak 6 buah, mempunyai makna 6 sifat utama atau ciri masyarakat lou dulowo limo lopahalaa yaitu:sifat tinepo-tenggang rasa, sifat tombulao-hormat, sifat tombulu-bakti kepada penguasa, sifat wuudu-sesuai kewajaran, sifat adatipatuh kepada peraturan, sifat butoo-taat pada keputusan hakim.

Tiang dasar (potu) khusus untuk golongan raja, jumlah tiang 32 sebagai perlambang 32 penjuru mataangin. Bentuk tiang pada bagian depan/serambi yang berbentuk persegi, ada yang 4, 6 atau 8 menunjukkan jumlah budak masing-masing raja. Bentuk ini kemudian menjadi tradisi yang diikuti secara turun temurun sekalipun bukan pada rumah bangsawan. Jadi tidak lagi mengandung makna tertentu tetapi hanya sekedar estetika. Jumlah anak tangga terdiri dari 5 sampai dengan 7. Angka lima melambangkan rukun islam serta 5 prinsip hidup masyarakat gorontalo, yaitu: Bangusa talalo, Lipu poduluwalo, Batanga pomaya, Upango potombulu, Nyawa podungalo, artinyan keturunan dijaga, negeri dibela,diri diabdikan, harta diwakafkan/dikorbankan, nyawa taruhannya. Angka 7 bermakna 7 martabat (tingkatan nafsu pada manusia) yakni amarah, lauwamah, mulhimah, muthmainnah, rathiah, mardhiah, dan kamilan.

Atap dua susun pada melambangkan adat dan syariat. Pada bagian puncak atap awalnya terdapat Talapua yaitu dua batang kayu yang dipasang bersilang pada puncak atap menurut kepercayaan masyarakat Gorontalo sebagai penangkal roh jahat (sekarang sudah tidak ditemukan lagi). Tange lo bu'ulu yang digantung pada dinding bagian depan rumah di samping pintu masuk melambangkan kesejahteraan masyarakat Gorontalo.

\section{2) Tata Ruang}

Pola ruang yang berbentuk segi empat pertanda empat kekuatan alam yakni air, api, angin, dan tanah. Tidak ada aturan untuk penataan ruang kecuali pada saat awal mula pembangunan rumah tidak diperkenankan membuat kamar lebih dari 3 . Penambahan kamar dilakukan belakangan setelah rumah itu dihuni. Ini terkait dengan kepercayaan masyarakat gorontalo tentang 3 tahapan keadaan manusia yakni bermula dari tidak ada, ada dan berakhir dengan tiada (alam rahim, alam dunia, dan alam akhirat).

Terkait dengan letak kamar yang diletakkan berjejer kebelakang atau posisi bersilang sebaiknya posisi kamar tidur utama berada pada sisi kanan pada saat keluar dari rumah. Dengan harapan bahwa apabila si empunya rumah jika turun/keluar rumah tetap ingat untuk pulang, dan sebaiknya arah kamar melihat arah aliran sungai yakni apabila sungai mengalir dari utara ke selatan sebaiknya kamar dibuat menghadap ke utara dengan harapan dapat menampung rejeki yang mengalir seperti derasnya aliran air sungai mengalir. Untuk kamar tidur anak laki- laki berada pada bagian depan dan untuk anak perempuan pada bagian belakang. Aturan untuk tidak memperkenankan tamu laki-laki masuk ke dalam rumah (tamu laki-laki hanya sampai di serambe/teras) adalah merupakan ajaran islam yang tidak memperkenankan yang bukan muhrim masuk ke dalam rumah. Ini menunjukkan bahwa ajaran agama islam sudah diberlakukan sebagai suatu adat yang tidak boleh dilanggar. Pembeda fungsi ruang diperkuat dengan adanya Pihito berupa balok yang menonjol di atas lantai yang berfungsi sebagai 
pembatas dari fungsi ruang menandakan bahwa aspek privasi sudah menjadi perhatian utamanya setelah masuknya islam.

Letak dapur yang dipisahkan oleh jembatan dengan bangunan induk/utama menurut adat masyarakat Gorontalo bahwa dapur merupakan rahasia jadi setiap tamu yang bertandang tidak boleh melewati jembatan tersebut. Dan yang paling penting diperhatikan adalah perletakan dapur/tempat memasak yang tidak boleh menghadap ke kiblat, karena menurut kepercayaan masyarakat jaman dahulu rumah akan mudah terbakar. Gambar dibawah ini bentuk rumah tradisional Gorontalo

\section{ISI PENELITIAN}

\section{a. Gambaran lokasi Penelitian}

Secara geografis pemukiman Suku Bajo Torosiaje terletak di Kecamatan Popayato, Kabupaten Pohuwato, Provinsi Gorontalo, Ada dua perkampungan suku Bajo di Torosiaje. Pertama yaitu perkampungan suku Bajo di Torosiaje Jaya yang terletak di daratan, dan yang kedua perkampungan suku Bajo yang terletak di atas laut yaitu Desa Torosiaje laut. dengan tipe iklim tropis basah. Kawasan ini didominasi oleh penduduk yang bermata pencaharian utama sebagai nelayan. Jarak yang di tempuh dari Ibukota Provinsi Gorontalo sampai ke Desa Torosiaje ini lebih kurang $500 \mathrm{~km}$. Kalau menggunakan kendaraan pribadi, jarak Ibukota Gorontalo ke Desa Torosiaje menghabiskan waktu sekitar 6 hingga 7 jam.

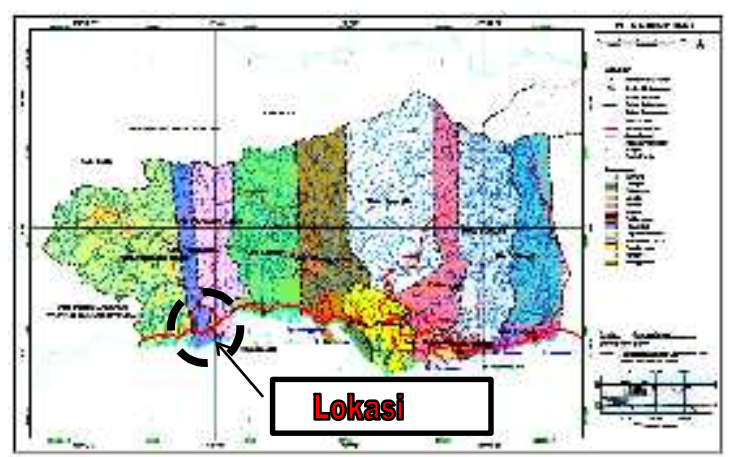

Gambar.11 Peta Kabupaten Pohuwato Lokasi Wilayah Penelitian

Sumber: Bappeda Kab. Pohuwato, 2016

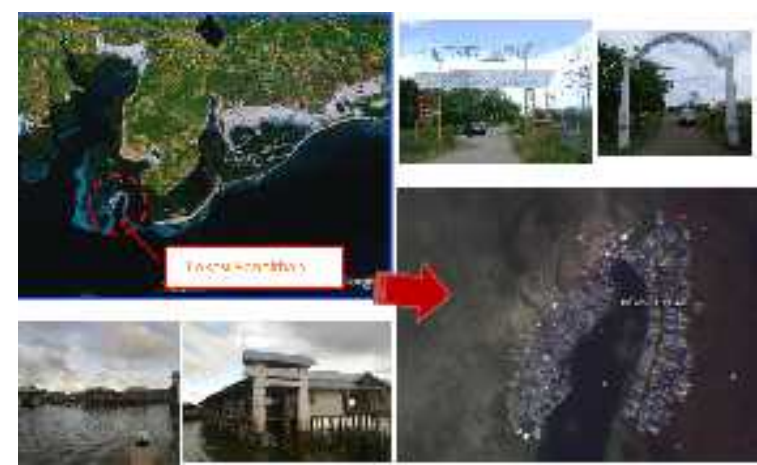

Gambar .12 Site Plan Desa Torosiaje
Sumber: Hasil Olahan dari Google Earth dan Foto Pribadi, 2017

b. Pola Hunian Permukiman Suku Bajo di Desa Torosiaje.

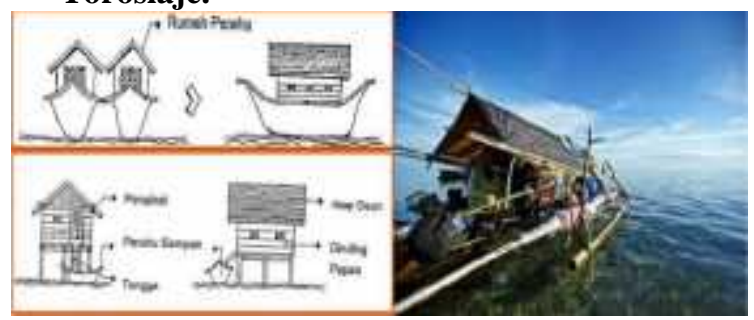

Gambar 12: Transformasi tempat tinggal Suku Bajo Sumber : Saman, 2014

Pada awalnya mereka hidup dan tinggal di rumah perahu yang disebutnya leppa yang memiliki panjang sekitar tujuh meter. Di atas perahu inilah mereka mengalami kehidupannya. Sejak lahir, berkeluarga sampai meninggal. Sebuah keluarga yang terdiri dari beberapa anggota menetap di atas perahu yang sempit tetapi panjang. Barangbarang yang mereka milikit terdapat di dalam leppa ini berupa alat penangkap ikan, alat untuk memasak dan alat-alat kebutuhan lainnya.

Leppa terbuat dari kayu yang sangat kuat dan dapat bertahan lama di laut. Atapnya terbuat dari daun nipah serta dengan mudah dapat digulung tergantung dari kondisi cuaca, walaupun saat ini ada yang menggunakan plastik sebagai bahan penutup di bagian samping. Perahu-perahu ini kelihatannya sempit-kecil dan penuh, tidak ada tempat untuk jalan dan hampir tidak ada tempat untuk berdiri, namun bagi mereka banyak yang merasa nyaman. Beberapa orang tua mengalami rasa sakit pada kakinya disebabkan kurang bergerak.

Terdapat dua konsep tentang ruang pada masyarakat Bajo. Pertama, tempat di mana mereka tinggal yang terpusat dan terbatas pada suatu kelompok (yang dulunya terjelma dalam leppa), dan sekarang pada desa. Kedua, bersamaan dengan itu juga berkaitan dengan tempat-tempat yang dikunjungi selama kehidupan masyarakat Bajo yang berpindah-pindah, hal ini berkaitan dengan sejarah mereka serta dengan desa- desa sama lainnya.

Kedua konsep tersebut berkaitan dengan kepribadian masyarakat Bajo dan tercermin dalam tindakan sehari-harinya. Sesungguhnya kedua pengertian tersebut memiliki makna yang berlawanan. Di satu sisi, ruang pada masyarakat Bajo bersifat menetap dalam leppa atau Desa, tetapi di sisi lain merupakan konsep dari kedinamisan masyarakat Bajo. Pengertian kedua merupakan segi lain dari kepribadian sosial ruang masyarakat Bajo pada waktu dulu, seluruh daerah yang memiliki beberapa kriteria ekologis bagi masyarakat Bajo, merupakan tempat-tempat yang mungkin didiami oleh orang Bajo.

Desa Torosiaje, dimana masyarakat Bajo berada, saat ini tersisa 3 (tiga) keluarga yang tinggal 
di leppa. Ketiga keluarga ini umunmya telah berumur tua. Sedangkan anak-anak mereka sudah tidak tinggal di leppa lagi Anak-anak mereka menempati rumah kayu yang dibuat di atas perairan. Tetapi juga ada yang telah pindah rumah yang pernah disediakan oleh pemerintah di pinggir pantai. Sebenamya keluarga-keluarga yang masih tinggal di leppa ini pernah diajak untuk tinggal bersama anakanaknya di rumah kayu atau di permukiman yang disediakan pemerintah, tetapi mereka kembali lagi ke leppa.

c. Sebaran Bangunan dan Kelompok Bangunan.

Pemetaan sebaran bangunan menurut orientasi bangunan menunjukkan bahwa rata- rata bangunan sebagian besar memiliki orientasi ke jembatan dan cenderung menghadap ke laut, terutama bangunan di jembatan utama yang sejajar dengan ruang terbuka laut. Pemetaan sebaran bangunan menunjukkan bahwa tata letak banguanan cenderung berjajar atau berderet- deret mengikuti arah jaringan jembatan yang membentang searah pintu masuk dan keluar.

Hasil pengamatan lapangan juga menunjukkan bahwa terdapat bangunan yang mengelompok dan membentuk suatu susunan yakni linier di sisi jembatan dan linier di keduasisi jembatan.

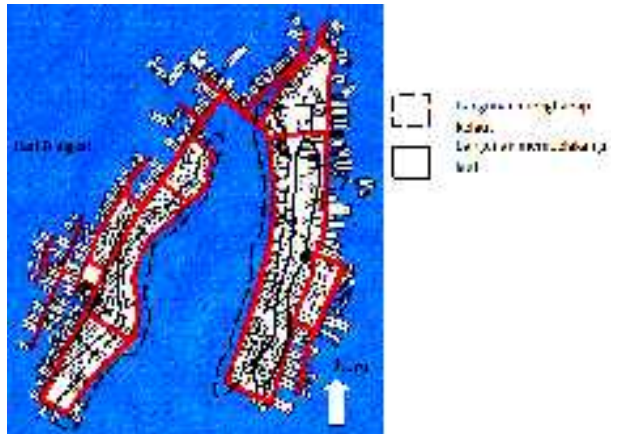

Gambar 13: Sebaran Bangunan Berdasarkan Orientasi Bangunan

Sumber: Peniliti, 2017

d. Sebaran Hunian Di Desa Torosiaje

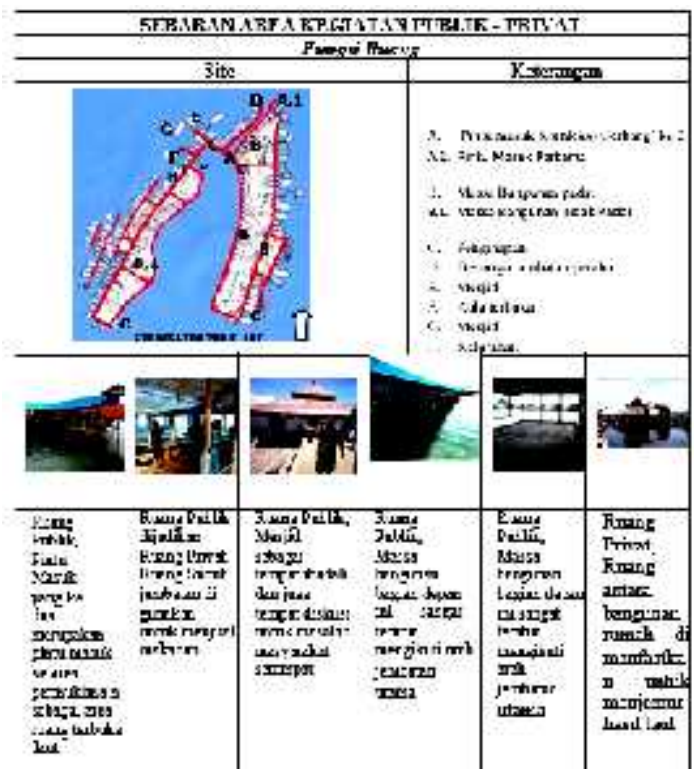

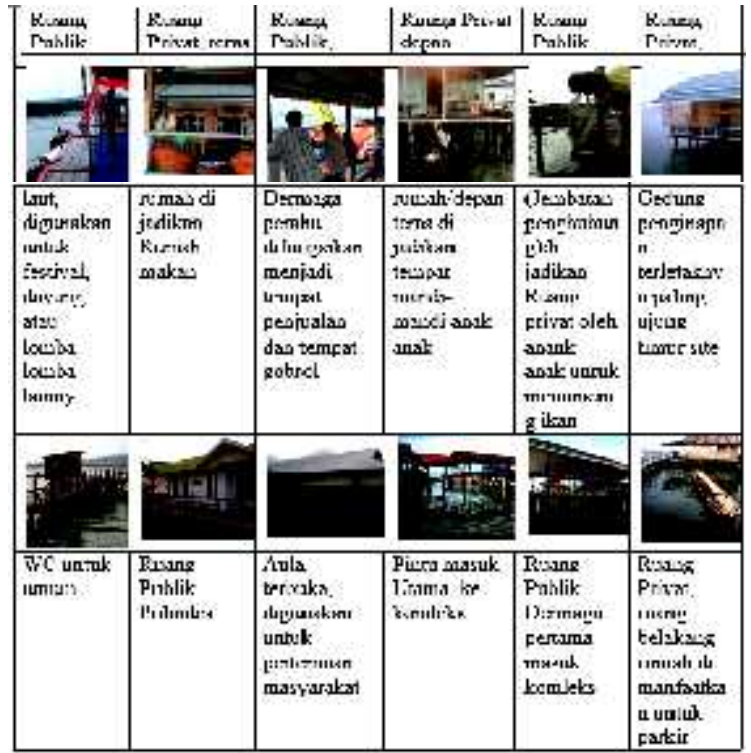

Gambar 14: Spasial Sebaran Area Publik - Privat Sumber: Peneliti 2017

Pemetaan Fasilitas Lingkungan dalam hal ini ruang Publik menunjukkan fungsi jembatan utama dan jembatan pembagi di lingkungan, terdapat keberadaan fasilitas umum. Di wilayah Permukiman suku Bajo di Desa Torosiaje laut tersebut fasilitas umum yang ada di permukiman. Fasilitas umum dalam hal ini adalah mesjid jembatan penghubung, dermaga tambatan perahu, ruang terbuka laut dan ruang tertutup (aula). Dalam perkembangannya ruang publik di permukiman suku Bajo di Desa Torosiaje laut dalam spasial ruang publik sering digunakan di antaranya sebagai tempat jemur, tempat duduk, warung, aktifitas, mengobrol dan ruang usaha tempat umum yang sifatnya terbuka.

\section{e. Bentuk Hunian Suku Bajo Yang di Pengaruhi Hunian Suku Gorontalo}

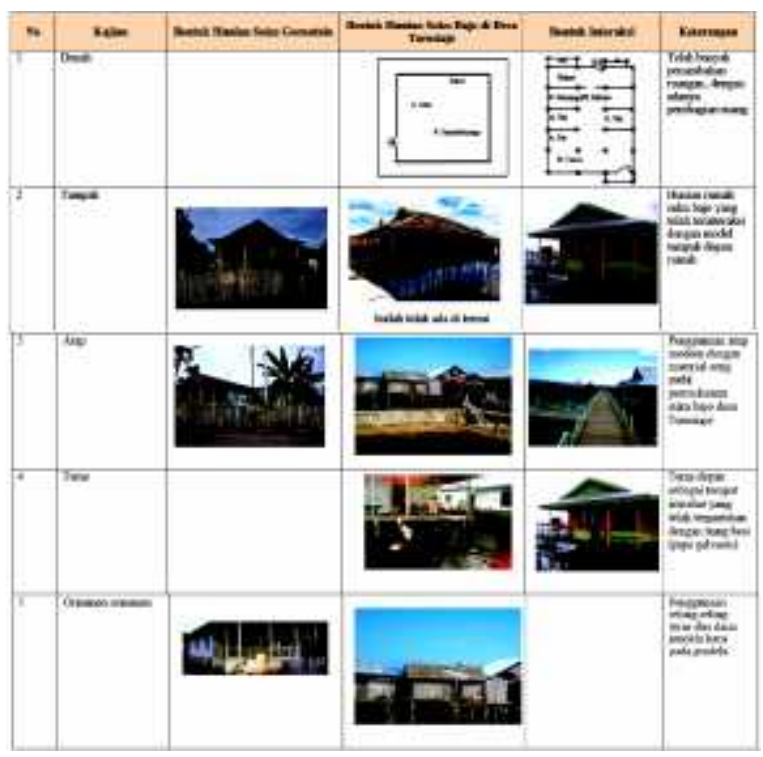




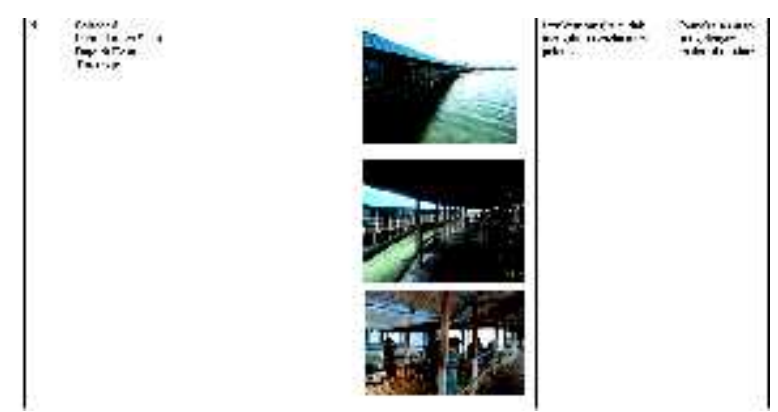

f. Gambar 15: Bentuk Hunian Suku Bajo Yang di Pengaruhi Hunian Suku Gorontalo Sumber: Peneliti 2017

\section{KESIMPULAN}

Perubahan bentuk hunian suku Bajo, sebagai berikut: Secara vertikal: terjadi perubahan fungsi pada bagian kolong rumah, dimana sebelumnya hanya berfungsi untuk menambatkan perahu berubah fungsi menjadi sebagai tempat usaha, tempat istirahat dan tempat bermain untuk anak-anak. Perubahan ini cendrung mengikuti fungsi kolong rumah tradisional suku Gorontalo yang menggunakan kolong rumah untuk berbagai macam aktivitas; Secara horisontal: rumah tradisional suku Bajo sudah melakukan penambahan atau penyekatan ruang-ruang sebagai wujud untuk menciptakan privasi dalam rumah. Seperti pemisahan antara ruang tamu, ruang keluarga, kamar tidur dan dapur. Perubahan ini dilakukan seiring dengan pengaruh interaksi di lingkungan sekitarnya terutama bentuk hunian suku Gorontalo; Secara stilistika: tampak adanya perubahan kemiringan pada atap rumah suku Bajo dimana pada awalnya berbentuk prisma landai sekarang berubah bentuk menjadi lebih lancip mengikuti bentuk hunian suku Gorontalo. Selain itu adanya perubahan pada sistem bukaan, dimana kondisi sekarang lebih banyak menggunakan jendela dibandingkan sebelumnya hanya sedikit jendela bahkan tidak ada sama sekali. Perubahan yang lain yakni, adanya penambahan ornamen- ornamen pada atap bubungan yang diberi simbol-simbol budaya Gorontalo seperti bentuk papan silang.

Tampak rumah suku Bajo: dilihat dari tampak depan, belakang maupun samping rumah tradisional sudah mengalami perubahan bentuk. Hal yang paling spesifik bisa kita lihat pada tampak depannya dengan penambahan atap pelana yang merupakan ciri khas rumah suku Gorontalo. Dari hasil analisa di atas, maka kecenderungan perubahan bentuk hunian suku Bajo mengikuti bentuk rumah tradisional suku Gorontalo sangat kuat dipengaruhi oleh adanya pengaruh interaksi dengan suku Gorontalo di desa Torosiaje Kabupaten Pohuwato

\section{DAFTAR PUSTAKA}

Budiharjo, Eko (1992), Sejumlah Masalah Permukiman Kota, Bandung: Alumni Byres, T. (1986), Agrarian Question From of Capitalist Agrarian Transition and The State
An Essay with Reference to Asia Paper International Workshop on Rural Tranaformation in Asia New Delhi.

Crowe, N (1977), Nature and the Idea of a Man Made World : An Investigation Into the Evolutionary Roots of From and Order in the Build Environment.

Hadi, Sutrisno (2000), Metodologi Research Jilid 2, Penerbit Andi, Yogyakarta. Halim, Deddy, (2005), Psikologi Arsitektur Pengantar Kajian Lintas Disiplin, Grasindo, Jakarta.

Kartono, J. Lukito (1999), Konsep Arsitektur Rumah Tinggal Tradisional dan Nusantara dan Pola Perubahannya, Seminar Nasional Arsitektur, UK. Parahiyangan, Bandung.

Koentjaraningrat (1982), Kebudayaan, Mentalitas dan Pembangunan, Jakarta, PT. Gramedia Pustaka Utama.

Kusnadi, (2008), Keberdayaan Nelayan dan Dinamika Ekonomi Pesisir, Penerbit ArRuzz Media, Yogyakarta.

Laurens, Joyce Marcella, (2004), Arsitektur dan Perilaku Manusia, Grasindo, Jakarta

Rapoport, Amos (1977), Human Aspect of Urban Form, Pergamon Press Inc, New York.

Rapoport, Amos (1969), House Form and Cultures of Architecture, L.Lorens, Barcelona.

Sawe, Dahlan. A. (1985/1986), Profil Masyarakat Bajo di Desa BajoE Kab. Bone. Penelitian, Lembaga Penelitian UNHAS, Ujung Pandang.

Saman, Satar (2014) Pola spasial permukiman suku bajo di Torosiaje laut, provinsi Gorontalo, Tesis Program Pascasarjana-Fakultas Teknik universitas Gadjah Mada, Yogyakarta 